\title{
Interplay of sediment supply and lake-level changes on the margin of an intrabasinal basement high in the Late Miocene Lake Pannon (Mecsek Mts., Hungary)
}

\author{
Soma Budai ${ }^{1} \cdot$ Krisztina Sebe $^{2} \cdot$ Gábor Nagy $^{2} \cdot$ Imre Magyar $^{3} \cdot$ Orsolya Sztanó $^{1}$
}

Received: 22 June 2018 / Accepted: 13 June 2019 / Published online: 11 July 2019

(c) The Author(s) 2019

\begin{abstract}
Lake Pannon, covering the Pannonian Basin (Hungary) during the Late Miocene, had a complex lake bottom with deeper subbasins and intrabasinal basement highs, sometimes emerging above the lake level as islands and peninsulas. Above structural highs, the basin fill sequence usually commenced with deposition of transgressional, locally sourced coarse-grained deltas. These deposits are overlain by distally-sourced deltaic bodies associated with the prograding delta system that gradually filled up the entire basin. The transition between these two distinct delta systems was studied in a large outcrop on the edge of a former basement high (Mecsek Mts., southern Hungary). The transgressional phase is represented by the deposition of a mass flow dominated fan delta body, fed by local material from a granitic catchment area. An overlying fossil-rich, clayey unit records an episode for which sediment delivery into the basin was curtailed, possibly due to submergence of the granite body. The deposition of these two units took place between 8 and $6.8 \mathrm{Ma}$. The onset of sedimentation associated with the arrival of the distally sourced regressive delta system (around $6.8 \mathrm{Ma}$ ) is represented by deposition of shoreface sediments. This unit is characterized by distinctive bioturbation and storm related, sand filled scour-fills. Resedimented local material that forms mm thick, coarse laminas in the scour fills is indicative of denudation due to tectonic events and implies coupled storm-flood sedimentation. The deposition of the two distinct delta bodies and the interplay between tectonic events and lake-level changes occurred during a relatively short, ca. 1.5 Ma long time interval.
\end{abstract}

Keywords Upper Miocene $\cdot$ Lake Pannon $\cdot$ Hungary $\cdot$ Fan delta $\cdot$ Storm sedimentation $\cdot$ Hyperpycnal flow

\section{Introduction}

Alluvial fans and fan deltas can form in various tectonic settings. Their facies architecture is sensitive to water level changes, climate, and catchment area lithology (Steel 1976; Nemec and Steel 1988; McCallum and Robertson 1995; Martins-Neto 1996; López-Blanco et al. 2000; Muravchik et al. 2014; Martini et al. 2017; Lin et al. 2018). The

Soma Budai

budai.soma@gmail.com

1 Department of Physical and Applied Geology, Eötvös Loránd University, Pázmány Péter sétány 1/C, Budapest 1117, Hungary

2 Department of Geology and Meteorology, University of Pécs, Ifjúság út. 6, Pecs 7624, Hungary

3 MTA-MTM-ELTE Research Group for Paleontology, POB 137, Budapest 1431, Hungary latter can determine the dominant depositional process, for instance debris flows tend to predominate in the case of clayrich catchment areas (Blair 1999a, b; Wagreich and Strauss 2005). Mud can be originated from the weathering of clayey deposits or, for example, of volcanic bedrock. The rate of weathering and, therefore, sediment influx to the basin is influenced by climatic factors (Leeder et al. 1998), which together with the sea/lake level fluctuations can determine the stratigraphic patterns of the fan deltas (Fernández et al. 1993; Gawthorpe et al. 1994; Postma 1995; Ghinassi 2007; Martini et al. 2017). Coarse-grained deltas formed along intrabasinal structural highs can be more dependent on baselevel fluctuation (Zhang et al. 2018), because it can alter the subaerial extent and the relief of the basement high which acts as the catchment area of the delta.

Locally-sourced, coarse-grained deltas formed around intrabasinal highs during the transgression of the Late Miocene Lake Pannon (Sztanó et al. 2016), which occupied the Pannonian basin (Hungary) until Early Pliocene 


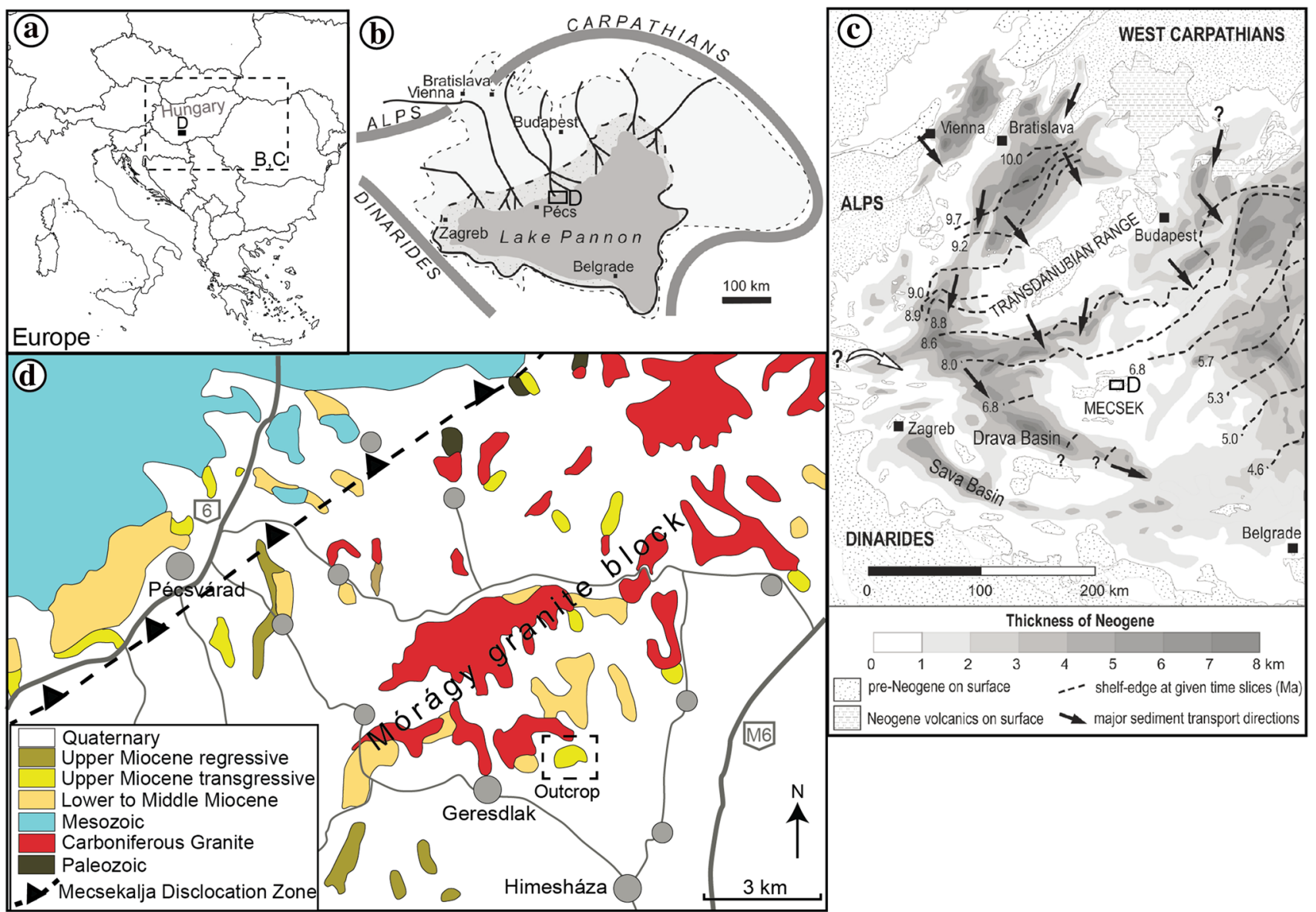

Fig. 1 a Location of the Pannonian Basin. Letters mark the area zoomed in b-d. b Simplified paleogeographic sketch of Lake Pannon within the Pannonian Basin, ca. 6.8 Ma ago (Sztanó et al. 2015). At this time, deltaic bodies were deposited in the study area. c Presentday depth of the pre-Neogene basement. The basement is divided by deep sub-basins with several km thick sediments and elevated basement highs like the Transdanubian Range and the Mecsek, where the study area is located. Dashed lines indicate the shelf edge prograding across the basin (Magyar et al. 2013). d Simplified geological map of the area; the outcrop is located at the eastern edge of the granite body

\section{Geological setting}

overlain by deltaic bodies fed by fine sediment shed from the remote Alpine-Carpathian region and deposited during the regressional phase of the basin fill (Magyar et al. 2013; Thamó-Bozsó et al. 2014; Sztanó et al. 2015, 2016). The direct superposition of these distinct delta bodies has not yet been described from outcrops.

The aim of this study is to describe the depositional settings of two superimposed deltaic bodies, associated with the two different deltaic systems, as exposed in a large sandpit that uniquely records their transition in southern Hungary. We also characterize the basinal processes responsible for their deposition and superimposition. The study was accomplished by specific research objectives, such as giving detailed sedimentological description to determine the depositional environments and lake level changes, and carrying out structural and paleontological analysis to constrain a structural and time framework for the deposition.
The outcrop is located within the back-arc Pannonian Basin, shaped originally during the Early-Middle Miocene rift phase, mostly by low-angle normal and strike-slip faults (Horváth and Royden 1981; Tari and Horváth 1992; Horváth and Cloetingh 1996; Fodor et al. 1999; Horváth and Tari 1999; Balázs et al. 2016). The major part of the basin-fill succession, however, was deposited during the Late Miocene-Pliocene ("Pannonian") post-rift phase, in the brackish Lake Pannon covering most of the basin (Fig. 1b). The lake developed over a complex topography inherited partly from the rifting, partly from early postrift compression. In this way, commonly fault-bounded emerged basement highs alternated with basins of various depth (Fig. 1c) (Magyar et al. 2004; Sztanó et al. 2015).

The sedimentary fill in the deeper sub-basins follows a uniform pattern: profundal marls are overlain by 
basin-center turbidites, slope deposits, stacked deltaic bodies, and the sequence is capped by alluvial deposits. The gradual fill of the basin resulted from large amount of sediments shed from Alpine-Carpathian areas (Magyar et al. 2013). Above elevated basement highs, which formed islands or peninsulas in the beginning and were flooded only later, the sedimentary record is incomplete and more diverse since the flooding led to the variation of partial or full inundation of these areas. Here, the sedimentary sequence usually starts with transgressive, locally sourced shoreface and/or delta sediments, occasionally overlain by sublittoral shales (Magyar et al. 2004; Cziczer et al. 2009). As the prograding Alpine-Carpathian delta system reached the area (Fig. 1c), the depositional environment changed depending on the water depth. In the case of shallower water $(20-30 \mathrm{~m})$, distally sourced prograding deltaic successions were deposited above the locally sourced sediments (Sztanó et al. 2013; Thamó-Bozsó et al. 2014).

The research area considered here is located on the eastern edge of the Mecsek Mts. in Southern Hungary, close to the villages of Himesháza and Geresdlak (Fig. 1). The pre-Late Miocene basement of the area is formed by Carboniferous granite and overlying Early to Middle Miocene silicilastic and carbonatic sediments, deposited during the syn-rift phase of the basin evolution (Hámor 1970; Balla and Gyalog 2009; Sebe et al. 2015). Middle Miocene limestone is subaerally exposed in a small part of the studied outcrop (Figs. 2, 3) while the granite crops out ca. $300 \mathrm{~m}$ to the north. The granitic body and its overlying sediments are separated from the main Mesozoic body of the Mecsek Mountains by a strike-slip zone (Fig. 1) which was active during the whole Cenozoic era (Csontos et al. 2002).

\section{Methods}

This study is field based. During the field work, $\mathrm{cm}$ scale facies analysis and lateral correlation of three logged sections (altogether ca. $120 \mathrm{~m}$ ) have been carried out in an abandoned sandpit. For determining the temporal constrain of the deposition, ca. 220 fossils have been collected. Dip-direction of structural elements, mostly deformation bands, and bedding have been measured and plotted on stereographic projections to reconstruct the structural deformation history. For a detailed summary of the identified facies see Table 1.

\section{Sedimentary features}

The studied section can be subdivided into four units considering the grain size and the grain composition (Figs. 2, 3 ). The lowermost unit (gravelly, arkosic unit) is composed of granite-derived (feldspar, quartz, granite rock fragments) coarse-grained material. The sandy, non-arkosic unit (Figs. 2, 3) is dominated by, sandy-silty material (Table 1). They are divided by a clayey unit, which is also represented at the top of the sandy unit (Figs. 2, 3).

\section{Gravelly, arkosic unit}

\section{Description}

The $14 \mathrm{~m}$ thick unit represents the lowermost part of the Upper Miocene sequence (Figs. 2, 3), unconformably overlying a Middle Miocene limestone. Its four facies are composed of coarse-grained, granite-derived (quartz, feldspar, granite rock fragments), generally poorly sorted material (Table 1). They can be discriminated upon grain-size and

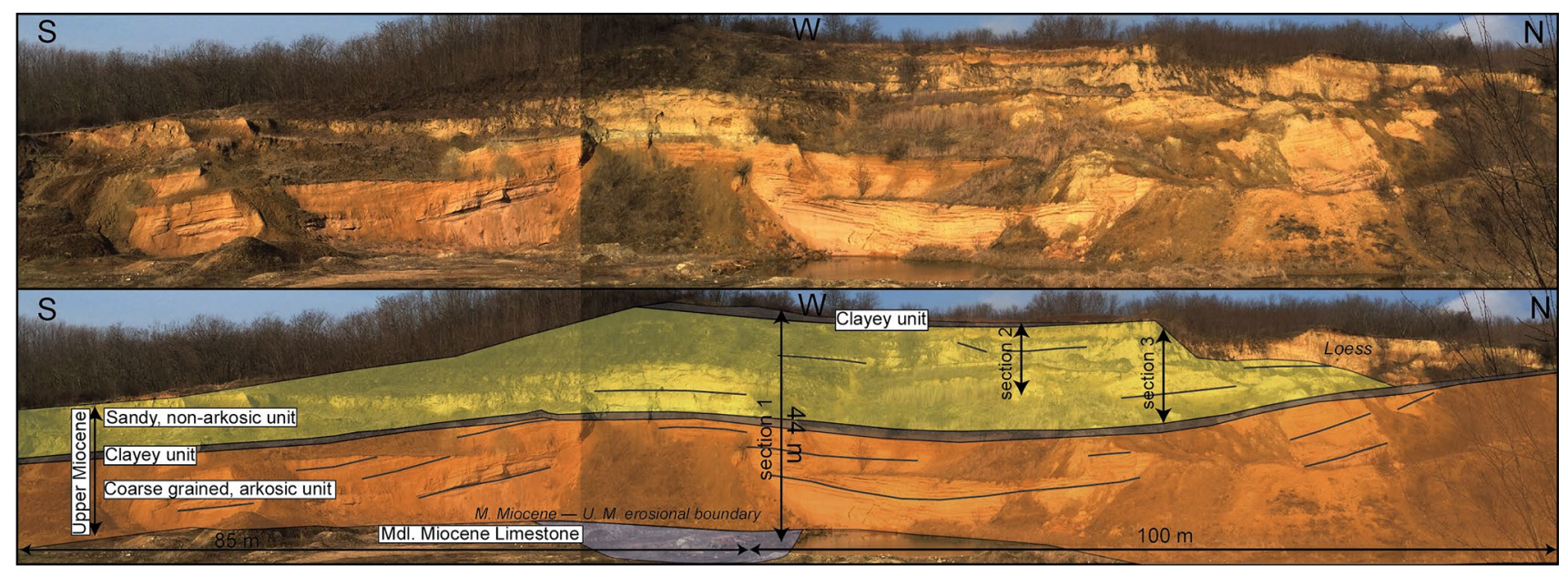

Fig. 2 Photograph of the studied outcrop showing the stratigraphic architecture of the three different units 


\section{LEGEND}

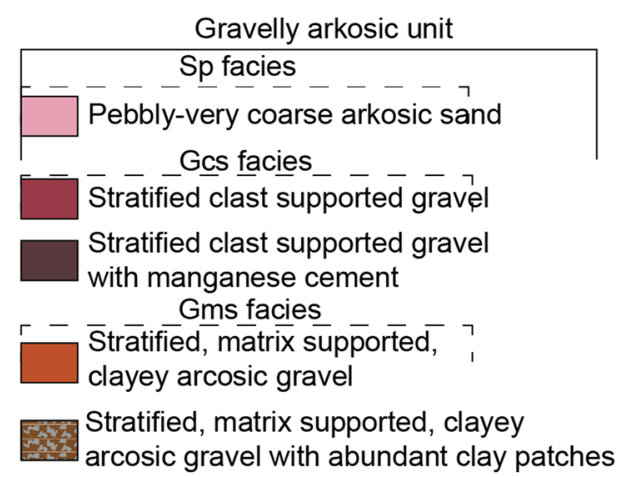

Clayey unit

Clay

\section{\begin{tabular}{|c|} 
Sandy, non-arcosic unit \\
\hline Ssl facies \\
\hline
\end{tabular} \\ $\checkmark$ Structureless silty-sand - । \\ संखेंत्र Structureless silty-sand with clay content} Sls and Ssf facies Channel lags (and Gfr facies) । Very fine sand with sedimentary structure

$\equiv$ Quasi-planar lamination

$\equiv$ Planar lamination

Slimbing current ripple

$\mathrm{HHH}$ Concretions

Combined flow sequence

2 Bioclasts

$\longrightarrow$ scour-fill
Erosional strata boundary

\section{$\sim$ Bioturbated strata boundary}

6and

霍輁 silt

点点 clay

$\because \because$ pebble

limestone
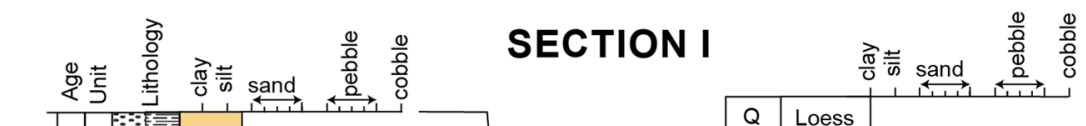$$
\begin{aligned}
& 20 \\
& 19 \\
& 18 \\
& 17 \\
& 16
\end{aligned}
$$

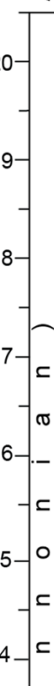

14

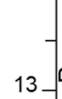

$13-\sqrt{2}$

13

$12-$

$11-$

10

$9-\Sigma$

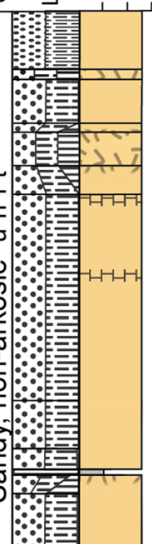

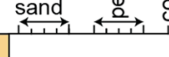
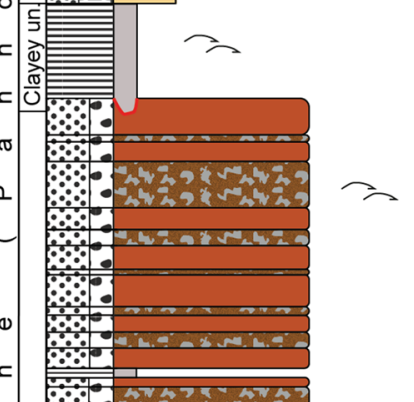

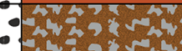

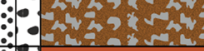

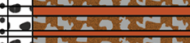
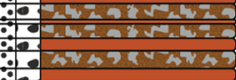

(1)

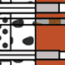

$8-$

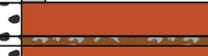

$-0$

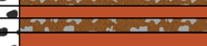

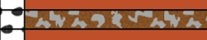

$7-2$

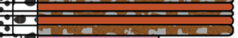

- 2

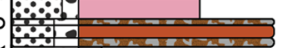

6

0

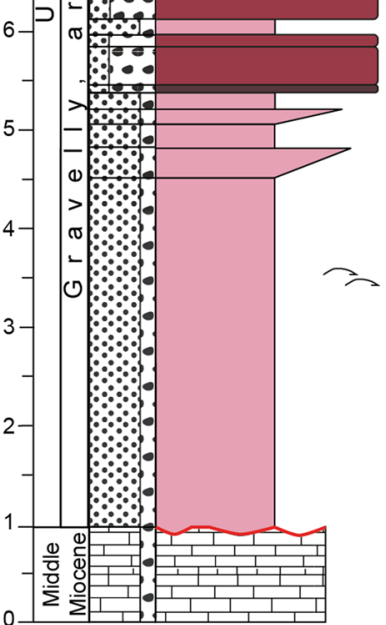

44

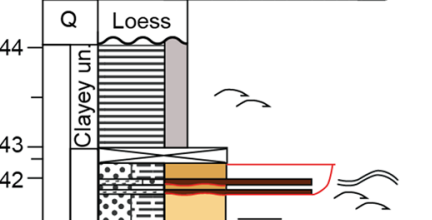

$38=$

37

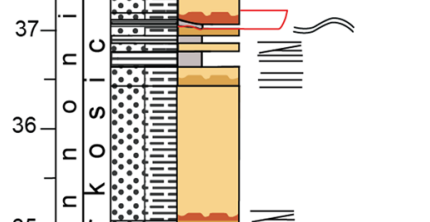

.

$\pi$

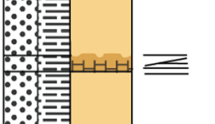

3

30

29

$28=$

$27-$

$26-$

$26-$

$\sim \sqrt{1,5 \mathrm{~m}}$

글

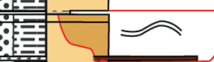

$\therefore$ 竞
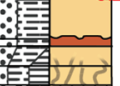

$\therefore$ 望

25

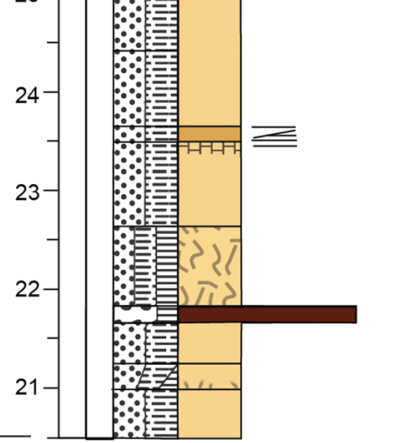

a 8 
4Fig. 3 The master sedimentary log of the outcrop. The Upper Miocene succession is deposited on Middle Miocene limestone. The lowermost $13 \mathrm{~m}$ of the studied succession is occupied by gravelly deposits of the gravelly, arcosic unit. This unit is overlain by ca. $1 \mathrm{~m}$ of grey clay. Between 15 and $42 \mathrm{~m}$ the sandy, non-arkosic unit is present, dominated by fine, sandy deposits. In different horizons, scourfills are present (see Figs. 6, 7)

the proportion and lithology of the matrix. The unit can be subdivided into three intervals, each built up by a dominant facies.

The lowermost interval is dominated by a ca. $4 \mathrm{~m}$ thick, moderately sorted, structureless, pebbly, very coarse-grained sand (Facies Sp) (Fig. 3). The grains are angular to subangular (Fig. 4b, c), and pebbles are randomly scattered and floating in the sand. The facies generally has amalgamated beds, but occasionally crude inverse grading is present (Fig. 4c). Locally, thin (1-5 cm), moderately sorted granulepebble beds ( $\mathrm{Gp}$ ) can occur.

Clast-supported, pebble-cobble gravel (Gcs) is the dominant facies of the ca. 2.5-3 m thick middle interval (Figs. 3, $4 \mathrm{a})$. The facies is poorly sorted and forms $10-50 \mathrm{~cm}$ thick beds, some of which exhibit inverse grading. The clastsupported framework is infilled by sandy (very-coarse) or occasionally clayey-sandy matrix. Similarly to the other facies, the clasts are angular to sub-angular. Limonite or manganese-oxide coating around the grains may occur. Thin beds of the Sp facies are also present. The change between the lower and middle intervals can be easily recognized by the appearance of strongly cemented, more resistant beds of the Gcs facies (Fig. 4a).

The uppermost interval attains up to $7.5 \mathrm{~m}$ in thickness (Fig. 3) and comprises 5-50 cm thick beds of stratified, matrix-supported, pebble-cobble gravel (Gms). The facies is poorly sorted, outsized clasts $(>30 \mathrm{~cm})$ can be present. Clasts are angular to sub-angular. Elongated clasts are often perpendicular to bedding, and just as in the case of the former three facies, a preferred clast orientation could not be observed. The matrix consists of clayey (coarse to very coarse-grained) sand. The clay in the matrix occurs in irregular, grey patches (Fig. 4d) with sharp boundaries and often containing sand-sized quartz and feldspar grains. The proportion of clay varies from bed to bed (Fig. 4d).

The Sp facies contains littoral and sublittoral, reworked intact and also fragmented bivalve shells, while the Gms contains only littoral mollusks.

\section{Interpretation}

The general lack of bedding of the Sp facies could be the result of the amalgamation of deposits of distinct gravity flows. The randomly dispersed larger clasts, the lack of orientation, along with occasional inverse grading suggest deposition from non-turbulent, plastic flows by frictional freezing (i.e., from less cohesive debris flows to grain flows) (Talling et al. 2012). The same depositional mechanism can be applied for the Gp and Gcs facies, considering the texture and the occasional inverse grading in the case of the latter. The beds of the Gms facies were presumably deposited from cohesive debris flows, given their high clay content, the outsized clasts, and clasts oriented perpendicular to bedding (Lowe 1982). The presence of bivalves suggests deposition under subaqueous conditions.

\section{Clayey unit}

\section{Description}

The gravelly, arkosic unit is overlain by a ca. $1-1.5 \mathrm{~m}$ thick clayey unit with an abrupt, sharp boundary. The grey, unbedded, monotonous clay lacks any sandy or gravelly intercalation and has moderate carbonate content (facies $\mathrm{C}$ ). In the clay, well preserved, sometimes articulated mollusk shells occur, although dissolved shells are also present. Similar deposit overlies the sandy, non-arkosic unit, and forms the uppermost unit of the Late Miocene succession.

\section{Interpretation}

Based on the lack of any sediment coarser than clay and the dominance of sublittoral mollusks, the clay was deposited from suspension settling in an environment without agitation of the waves, below the storm wave base.

\section{Sandy, non-arkosic unit}

\section{Description}

The unit overlies the clayey unit with a sharp boundary. It is composed of silty, very fine-grained sand through its ca. $25 \mathrm{~m}$ thickness. Few $\mathrm{cm}$ to meter thick beds of structureless, silty, very fine sand (Ssl) comprise the major part of the unit. The basal surface of the beds shows irregular, wide or narrow pockets tapering downwards (Fig. 5d). Clay filled, round burrows and moulds of littoral mollusks are present (Fig. 5a). Occasionally horizontally elongated carbonaterich concretions occur in distinct, bed-parallel horizons. Although the facies is generally structureless, remnants of (quasi-)planar lamination (Arnott 1993) or very low angle cross lamination can be recognized in some of the beds.

Beds of the Ssl facies are divided by a couple of $\mathrm{cm}$ thick, extensive beds of laminated, very fine-grained sand (Sls). The beds have sharp basal and irregular upper contact (described at the previous facies). Thin, a couple of mm thick, very-coarse-grained sand laminae (composed of quartz and feldspar) can be present above the sharp base 


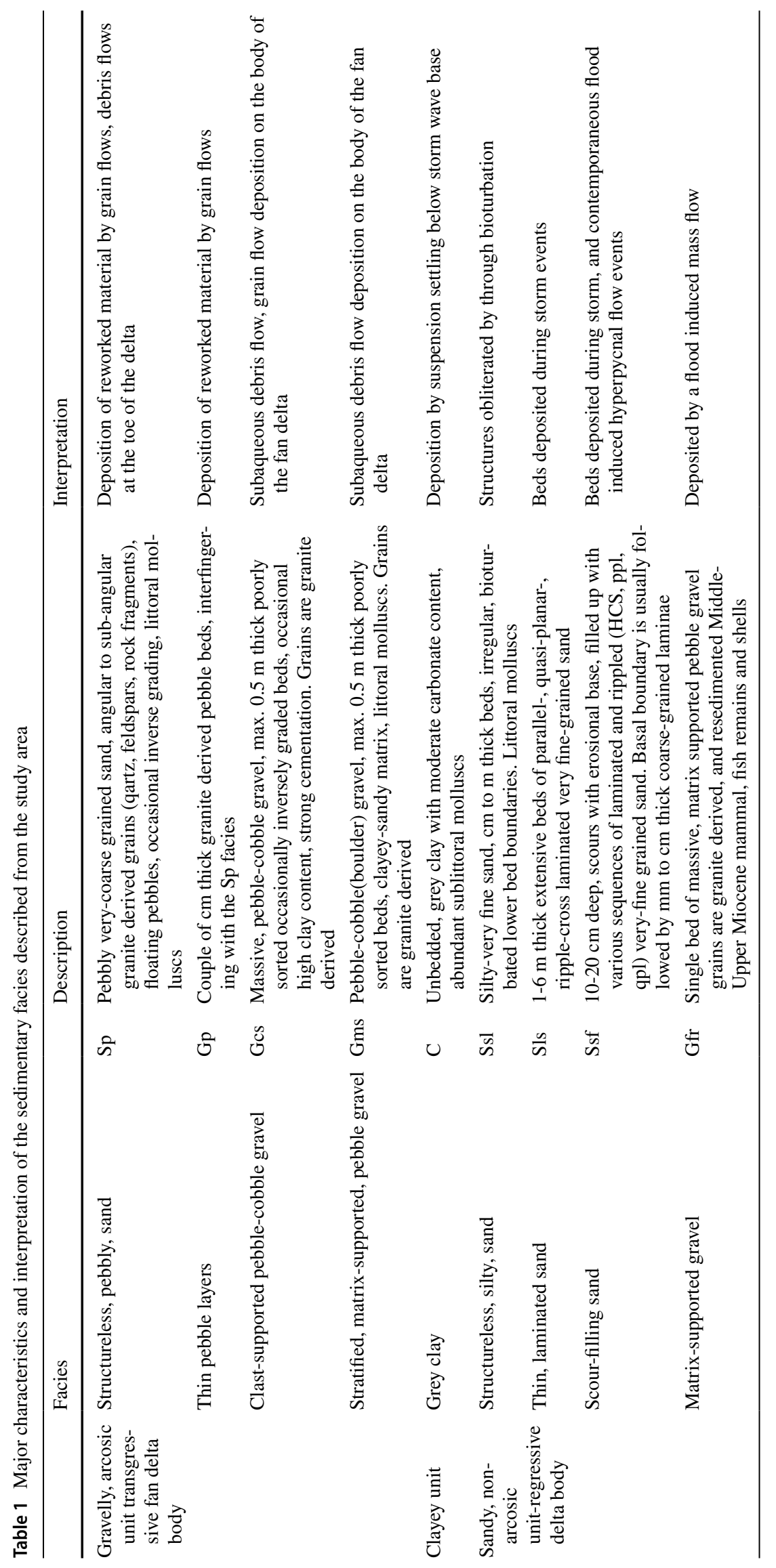




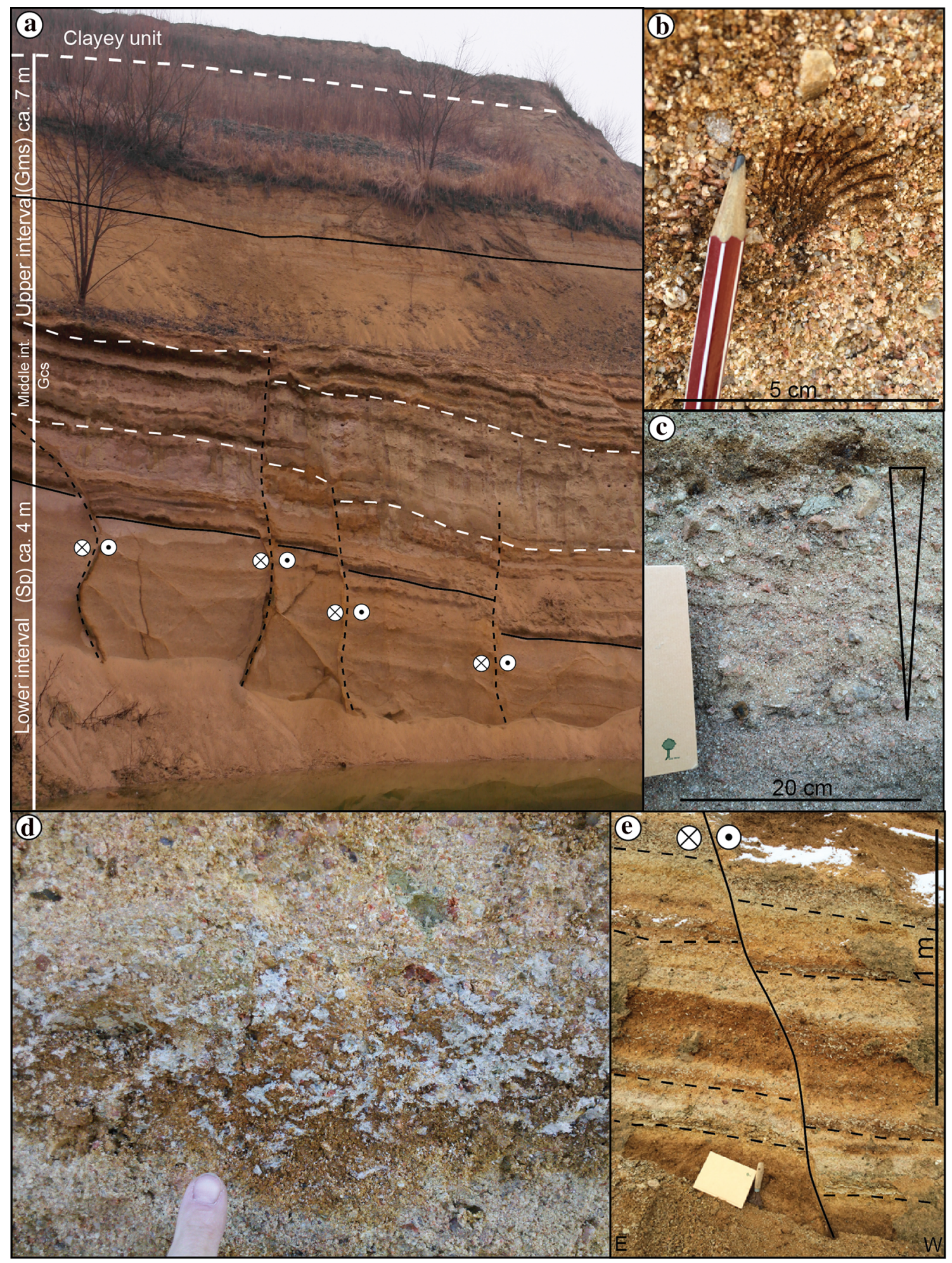

Fig. 4 a Stratigraphic architecture of the coarse-grained, arkosic unit, with syn-sedimentary deformation bands. b A littoral mollusk (Lymnocardium sp.) among granite derived sand grains in the Sp facies. c Inversely graded bed (from coarse sand to pebbles) of the $\mathrm{Sp}$ facies. d Layers of the Gcs facies with different clay content and limonitic coating around the grains, faulted by syn-sedimentary movements. $\mathrm{e}$ Syn-sedimentary faulting in the Gms facies 

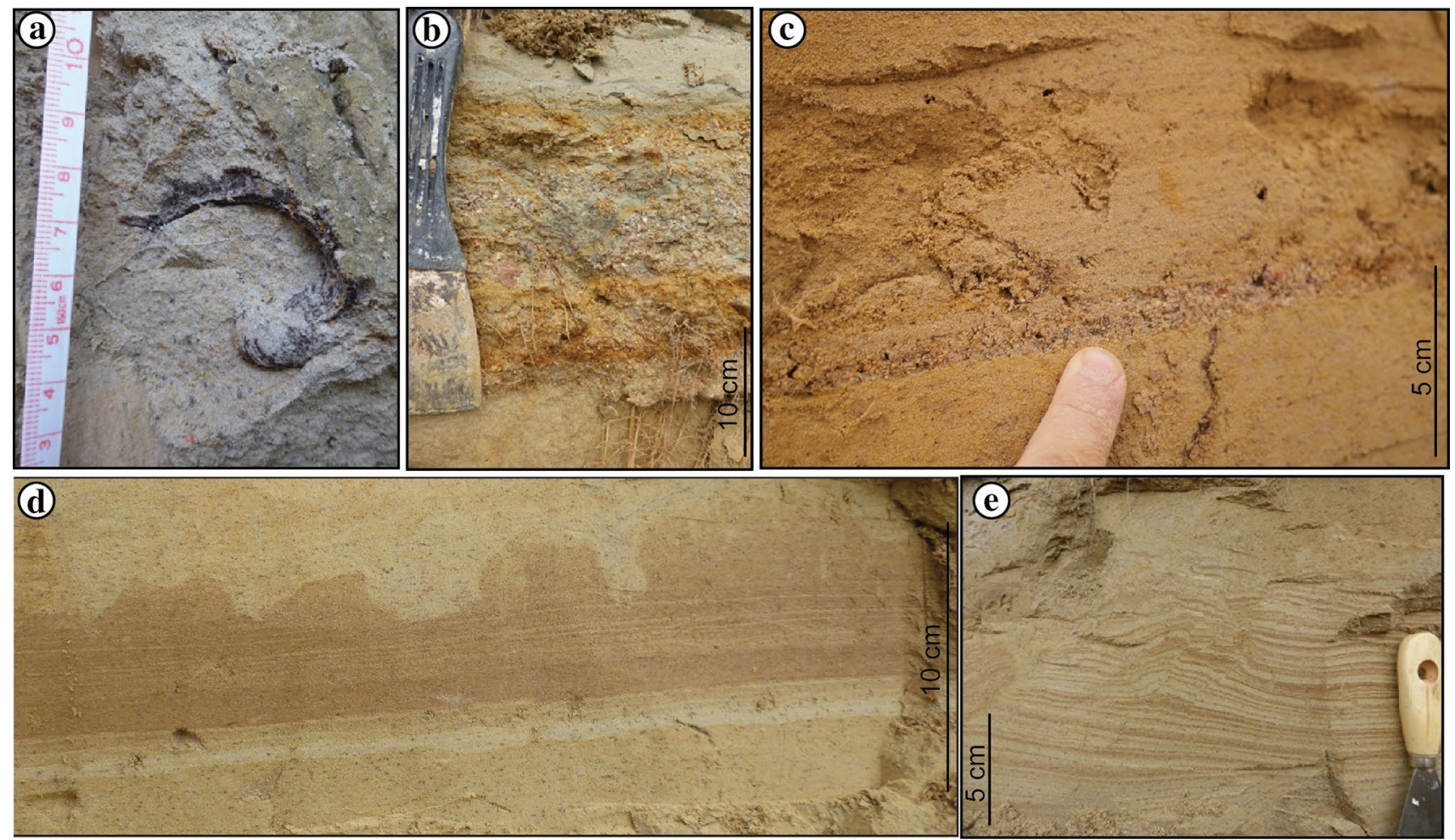

Fig. 5 a A littoral mollusk (Lymnocardium sp.) in the Ssl facies. b Coarse-grained bed of the Sfr facies, which represents a non-recurring mass flow event transporting local sediment. c Thin channel lag composed of qartz and feldspar grains, overlain by planar laminated

of the beds, which are usually overlain by (quasi-) planar laminated or low angle cross laminated sand.

A single, poorly sorted, matrix-supported gravel bed (Gfr) occurs in the lower part of the unit [at ca. $21.5 \mathrm{~m}$ in the section (Fig. 3)]. The ca. $50 \mathrm{~cm}$ thick, laterally extensive bed is composed of angular to sub-angular granite-derived granules and pebbles in a clayey-sand matrix, not like any other in the sandy non-arkosic unit (Fig. 5b). It contains resedimented, Middle Miocene bioclasts and redeposited Upper Miocene limonitic moulds of bivalves.

In five distinct horizons, concave-upward erosional features are present (Figs. 6,7a). They can be spoon shaped or have a curved base with nearly $90^{\circ}$-steep walls (Fig. 6). The former ones tend to be shallower, $20-30 \mathrm{~cm}$ deep, while the other ones can reach up to $60 \mathrm{~cm}$ in depth. Both can be more than $2 \mathrm{~m}$ wide (Fig. 6). The infilling of the scours is composed of laminated, (silty) very-fine grained sand (Ssf) (Fig. 7).

Based on the sequence of the different sedimentary structures within the scour-fills, an idealized sequence can be described (Fig. 7b). The basal erosional, scoured surface is usually overlain by a 3-4 mm thick, coarse material, composed of angular to subangular quartz and feldspar grains with a size of very coarse sand (Fig. 5c). Generally, this very fine-grained sand. d Thin bed of the Sls facies which shows severe bioturbation after the storm and/or flood events which deposited the layer. e Soft-sediment deformation in a scour filling sequence

is followed by planar laminated sand, usually overlain by quasi-planar and undulating lamination (Arnott 1993; Basilici et al. 2012). The following interval is characterized by usually anisotropic and small-scale hummocky crossstratification, similar to the ones described by Myrow et al. (2002), Dumas et al. (2005), Tinterri (2011) and Basilici et al. (2012) or to micro-HCS described by Eoff (2014). The hummocky interval is usually overlain by current ripples or a climbing cross laminated sand (type-B and type-S with lee and stoss side evenly preserved; Allen 1973). The sequence can be capped by thin mud drape or planar laminated sand. Soft sediment deformations (slumping) are present but not commonly.

The 2C scour-fill (Fig. 7d) shows the most complex sequence. The planar-laminated interval is followed by small-scale HCS, interfingering with cross-laminated sand and they are overlain by type-S climbing cross lamination. The sequence is then capped by planar lamination. In the cases of the $1 \mathrm{~A}$ sequence, the channel lag is directly overlain by large-scale HCS (Fig. 7c), which is followed by climbing cross lamination, and above that a couple of mm thick mud drape is present. In the 3A scour-fill (Fig. 7f), a thin mud layer interrupts an otherwise ideal sequence above the HCS interval. In some cases, the scour-fill sequence contains two 
Fig. 6 a, b Photograph and line drawing of the $2 \mathrm{C}$ scourfill. b, $\mathbf{c}$ Photograph and line drawing of the $1 \mathrm{~A}$ scour-fill. For a detailed photograph and sedimentary log see Fig. 7d, c, respectively
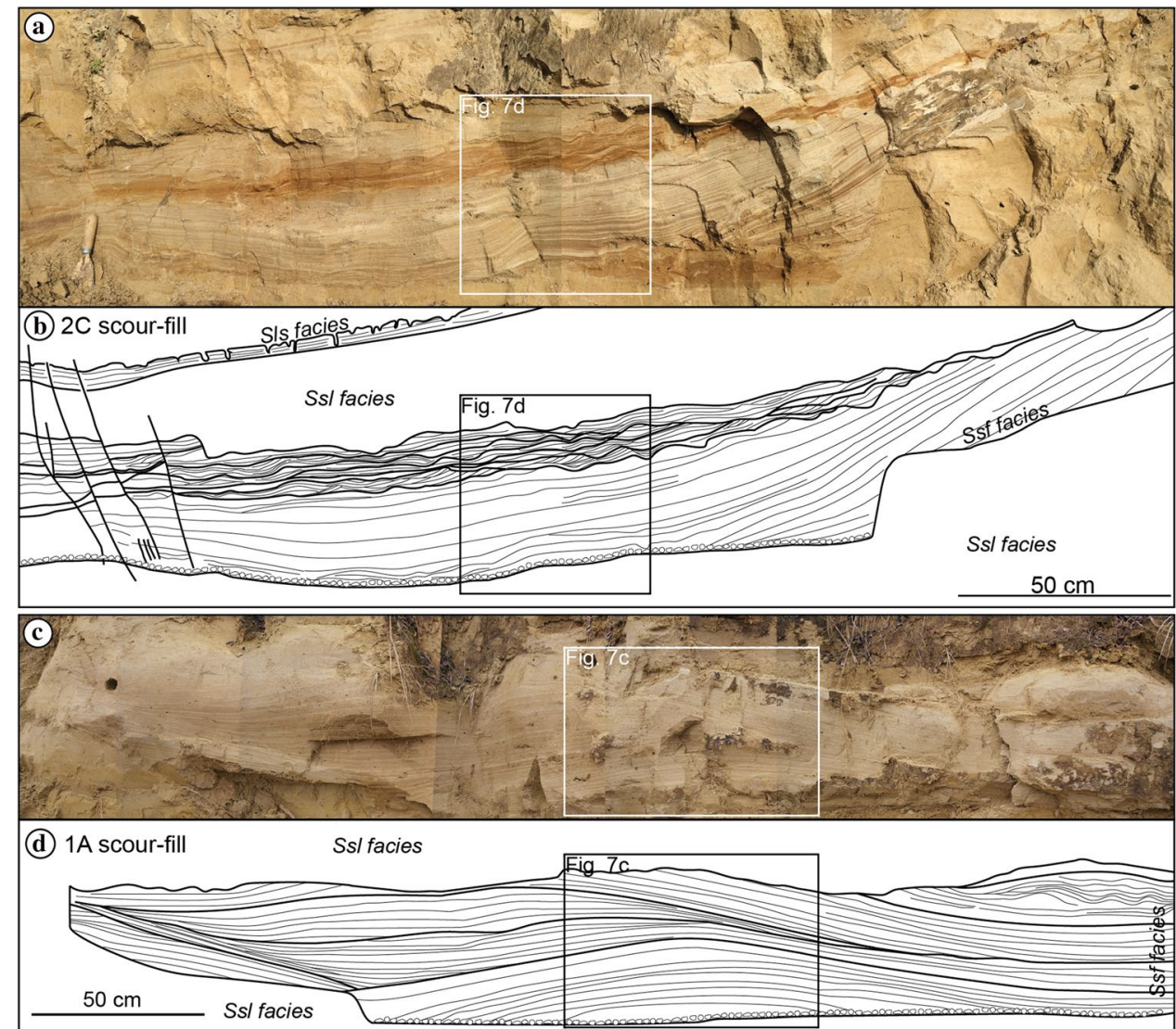

erosional surfaces, like in section of 5A (Fig. 7e), where the formation of an undulating planar laminated interval was interrupted or followed by recurring erosion and the deposition of a second and thicker channel lag within the same channel.

\section{Interpretation}

The presence of infaunal mollusks (Fig. 5a, d), burrows, and the remnants of sedimentary structures could mean that the beds of the Ssl facies were intensely reworked by bioturbation, which obliterated their original structure. Based on their sedimentary structures and sharp basal contact, the thin sandy beds of the Sls facies were formed during erosive unidirectional and partly combined flows. After these possibly rapid events, the upper part of the beds suffered intense bioturbation which resulted in the irregular boundary with the beds of the Sls facies (Fig. 5d). The lone clayey, poorly sorted gravelly bed of the Gfr facies was deposited from a cohesive debris flow (Lowe 1982) during a non-recurring event.

Scoured base, occasional soft sediment deformation, and post-depositional bioturbation can point to rapid deposition during erosional events that formed the scour-fills. The gradual transition between different sedimentary structures indicates progressive changes in the flow conditions during sedimentation. The scoured basal contact along with the coarser channel lags, as well as the following planar lamination, point to strong unidirectional currents (Bhattacharya et al. 2004). However, quasi-planar lamination indicates strong combined flow (Arnott 1993). The HCS, which represents the subsequent interval, is thought to be formed under combined oscillatory and unidirectional currents during the waning phase of storms (Hamblin and Walker 1979; Dott and Bourgeois 1982; Walker et al. 1982; Swift et al. 1983; Dumas and Arnott 2006). Arnott and Southard (1990) and Dumas and Arnott (2006) showed that only a minor unidirectional component is required to make the HCS bedform anisotropic, and it can be also produced by dominantly oscillatory flow (Dumas et al. 2005). Since it is possible that both plane beds and HCS can be stable at relatively low flow velocity under a high fallout rate (Leclair and Arnott 2005; Dumas and Arnott 2006; Tinterri 2011), the upward passage from HCS to plane lamination could be interpreted as a result of increasing fallout rate rather than an increased flow velocity (Tinterri 2011). This can be justified by the presence of type-S climbing ripples (Jopling and Walker 1968; Allen 1973) between the HCS and planar laminated interval, pointing towards high fallout rates (Fig. 7d) (Ashley et al. 1982; Yokokawa et al. 1995; Tinterri 2011). The 


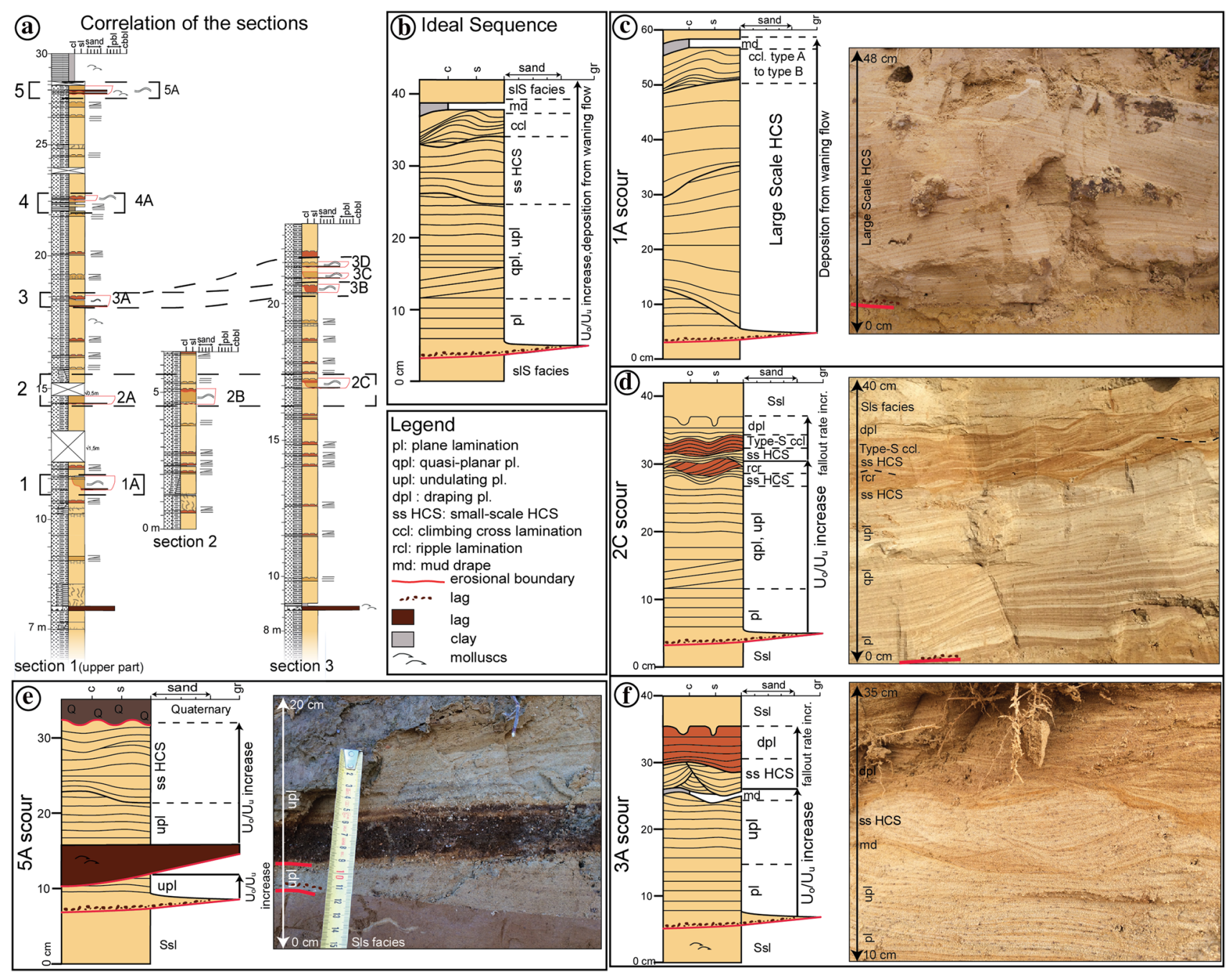

Fig. 7 a Correlation of the different scour fills and beds of Sls facies. b Idealized scour fill sequence. c-f Various scour-fill sequences, see description in the text

draping mud lamina on the uppermost part of the sequences represents suspension settling after the event (Fig. 7c, f). In conclusion, the vertical sequence of the different bedforms in each scour-fill can be interpreted as deposition from a combined flow, characterized by progressively increasing oscillatory flow component and/or fallout rate.

\section{Fossils}

The outcrop contains a rich fauna of mollusks endemic to Lake Pannon, with different assemblages being characteristic of the three units (Fig. 8). Bivalves usually appear as moulds and prints, making the species-level identification difficult and often uncertain; remnants of the original aragonitic shell material occur occasionally only in the clayey unit. In addition to mollusks, redeposited Middle Miocene vertebrate remains (teeth of sharks, rays and bony fishes, crocodile remains, Odontoceti teeth and vertebrae, Sirenia ribs) occur scattered in the sandy unit (Kazár 2005; Kocsis et al. 2009). Palynological samples from clays in the gravelly and clayey units failed to yield the stratigraphically important dinocysts.

The gravelly, arkosic unit contains limonitic moulds of littoral dreissenids and cardiids, such as Congeria cf. balatonica (Fig. 8f, g), Lymnocardium cf. proximum, L. dumicici, "Protoplagiodacna" sp., and Phyllocardium planum. Large moulds of $L$. cf. hungaricum, a species that occurs at both littoral and sublittoral depths, are common. Thin clayey layers of the unit contain moulds of sublittoral dreissenids, such as Congeria rhomboidea, $C$. cf. croatica, $C$. sp., and unidentified cardiids. The exclusively inarticulate valves in this unit indicate high-energy conditions, i.e., transportation or wave-reworking of the shells. 

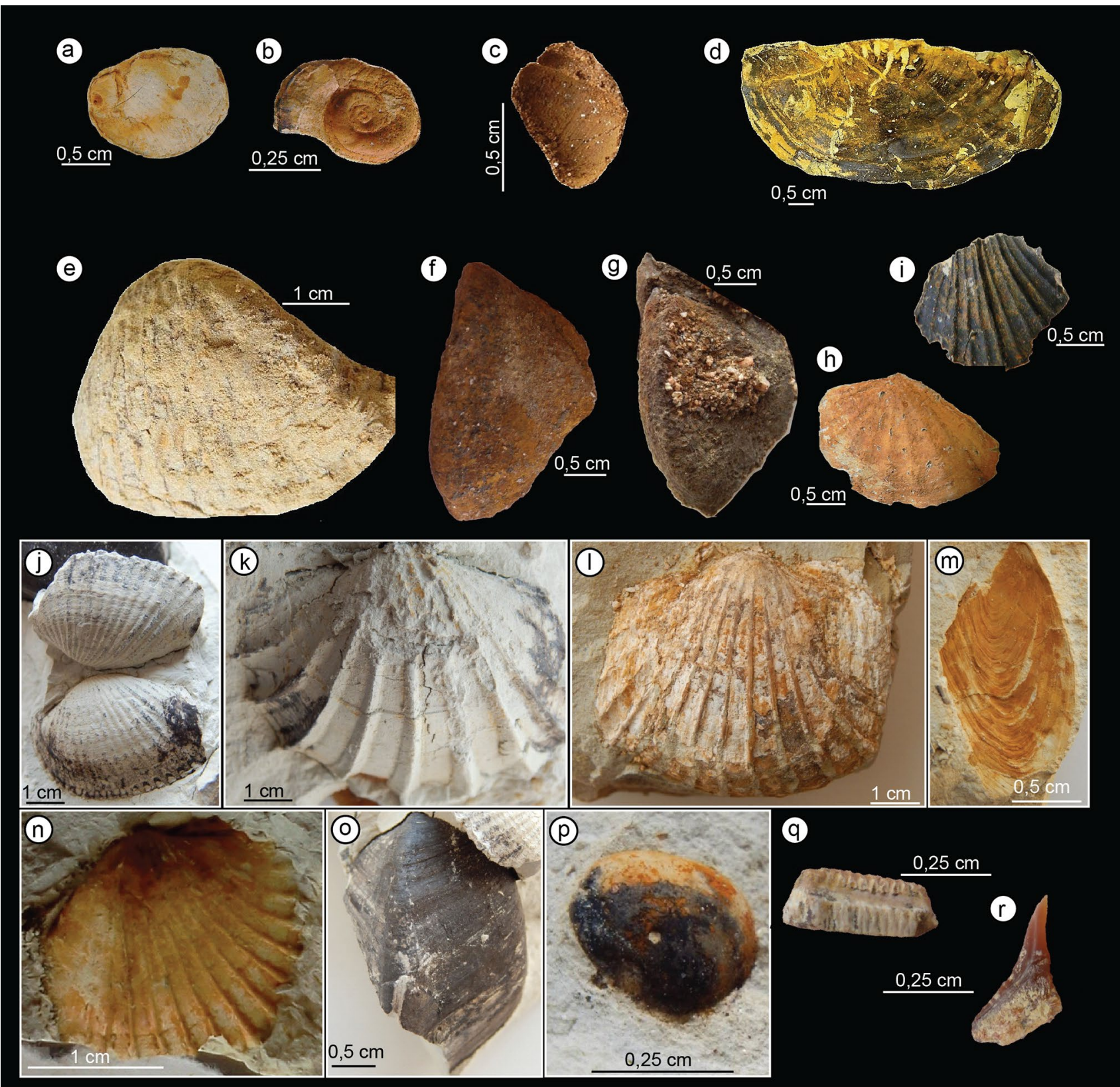

Fig. 8 Typical fossils of the outcrop. a Radix sp., b Gyrauluss sp., c Zagrabica sp., d Valenciennius sp., e Lymnocardium schmidti (Hörnes), f Congeria cf. balatonica Partsch, g Congeria cf. balatonica Partsch, h Phyllocardium planum (Deshayes), i Caladacna steindachneri (Brusina), j Lymnocardium majeri (Hörnes), k Lym-

The clayey unit has the most diverse fauna in the sequence, predominantly with sublittoral bivalves and gastropods, such as Congeria rhomboidea (Fig. 8o), C. zagrabiensis (Fig. 8m), Lymnocardium cristagalli (Fig. 8k, 1), L. majeri (Fig. 8j), L. cf. rogenhoferi, L. szaboi (Fig. 8n), L. cf. riegeli, "Pontalmyra" otiophora, Pisidium sp. (Fig. 8p), Planorbidae sp. (Fig. 8b), Radix sp. (Fig. 8a), and Valenciennius sp. (Fig. 8d). The clayey unit also contains the cardiids nocardium cristagalli (Roth), I Lymnocardium cristagalli (Roth), m Congeria zagrabiensis Brusina, n Lymnocardium szaboi (Lőrenthey), o Congeria rhomboidea Hörnes, $\mathbf{p}$ Pisidium sp., q ray tooth, $\mathbf{r}$ shark tooth (Hemipristis sp.)

Lymnocardium hungaricum and Caladacna steindachneri (Fig. 8i), which may occur in both littoral and sublittoral settings, a few specimens of the littoral Pontalmyra budmani and Phyllocardium planum (Fig. 8h), and a series of unidentified cardiids. The characteristically articulated valves reflect a calm environment.

The mollusk fauna of the sandy, non-arkosic unit is impoverished. Abundant single shells of only two bivalve 

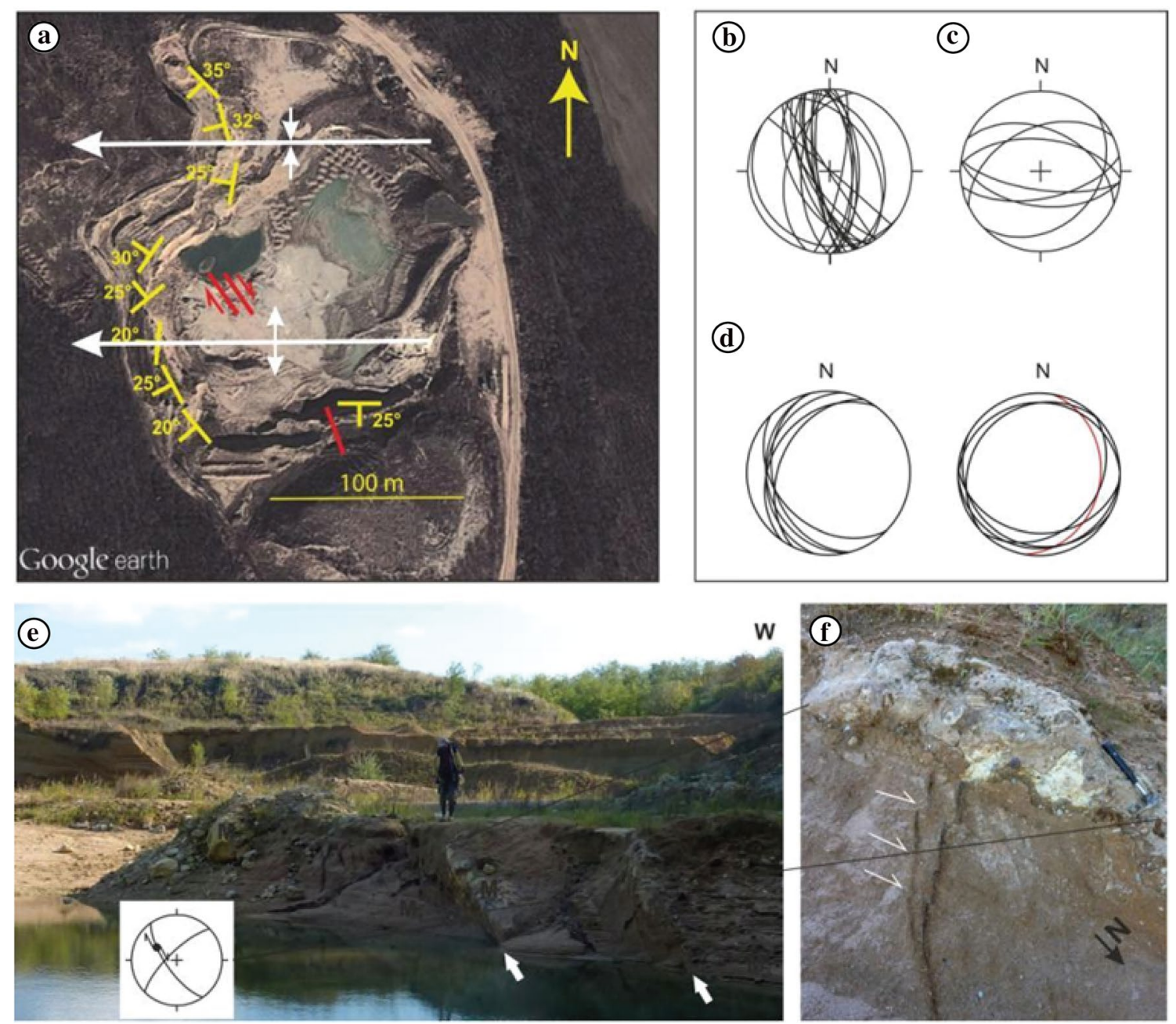

Fig. 9 Structural features. a Structural features in map view: bedding dips (yellow), major strike-slip faults (red), and fold axes (white). b Stereoplot of the oldest, syn-sedimentary faults in the gravelly, arkosic unit, backtilted with local bedding dip. $\mathbf{c}$ Stereoplot of later faults in the west wall, backtilted with fold axis plunge value. d Stereoplot of bedding dip data, original measurements and data backtilted

species (Lymnocardium ferrugineum, L. schmidti, Fig. 8e) in the Ssl facies indicate littoral environment. The laterally extensive coarse-grained, gravelly bed of the Gfr facies possesses a peculiar fossil assemblage: frequent Middle Miocene vertebrate fossils (e.g., shark and ray teeth (Fig. 8q, r), marine mammal remains) and limonite-cemented, heavily worn moulds of $L$. ferrugineum occur in the bed among granite pebbles. The coarse lag of scour-fill 5A contains both littoral (Zagrabica sp., Fig. 8c) and sublittoral (Lymnocardium szaboi) mollusks, referring to partial reworking of sublittoral lacustrine sediments. The overlying silty layer from the very top of the outcrop yielded the remnants of Lymnocardium cf. rogenhoferi, a sublittoral cardiid.

The entire mollusk fauna of the outcrop, including the redeposited specimens, belongs to the Congeria with fold axis plunge value. e Dextral strike-slip faults (white arrows) placing Middle Miocene limestone next to and onto Upper Miocene gravelly sand; stereoplot shows the orientation of faults and of limonitic fractures displaced by them. f Oblique view of one of the dextral faults from above, with parallel secondary faults displacing limonitecemented fractures

rhomboidea sublittoral and Prosodacnomya littoral zones (Magyar and Geary 2012) and indicate and age of $\sim 8-6.5 \mathrm{Ma}$.

\section{Structures related to syn- and post-depositional deformation}

The sandpit exhibits abundant deformation features, both brittle and plastic. Although structural geological studies have been conducted previously at the site (Csontos et al. 2002), as a result of the considerably increased extent of the exposure and the systematic investigation of fossils, more tectonic data could be gathered and the age of tectonic phases could be better constrained. 
The most abundant brittle structures are numerous NW-SE to NNW-SSE trending subvertical faults with limonitic cementation (Figs. 4a, e, 9b) occurring only in the gravelly, arkosic unit. Their apparent displacements in the vertical walls are either normal or reverse, typically not more than a few tens of cms. Upon close inspection, most of them are a couple of $\mathrm{cm}$ thick finer grained bands, therefore, strictly speaking they are deformation bands (Fossen et al. 2007); however, for the sake of simplicity, we refer to them as faults in this paper. Slickensides are lacking in the unconsolidated sediments; inferred from the offset of dipping beds, most of these faults are characterized dominantly by dextral strike-slip kinematics. Their displacement diminishes upward and they are sealed by the lower clayey horizon (Fig. 4a), thus their activity was coeval with the deposition of the gravelly, arkosic unit and ceased within a short time interval. This implies that they were only active around the start of sedimentation, which invokes the supposition that the beginning of Late Miocene sedimentation was tectonically controlled.

Similarly, oriented faults occur in the southern wall and at the bottom of the sand pit, displacing the gravelly, arkosic unit and the underlying Middle Miocene limestone. They are all primarily dextral strike-slip faults, with a minor reverse component, shown also by slickensides in the limestone. The Middle Miocene limestone is placed beside and onto the Upper Miocene gravelly sand by several parallel faults (Fig. 9e, f). Thin $(<10 \mathrm{~cm})$ Upper Miocene base gravel cemented on the faulted surfaces of the limestone indicates that the fault planes were exposed (i.e., had been active) by the beginning of Upper Miocene sedimentation. Secondary fault planes parallel with the major ones offset the base of the Upper Miocene gravelly sand as well as perpendicular, NE-SW striking limonite-cemented joints (Fig. 9f), showing that the activity of the fault planes both pre- and post-dates the start of Upper Miocene sedimentation.

Based on biostratigraphic dating with mollusks, the dominantly strike-slip deformation probably provoking the start of lacustrine sedimentation happened between 8 and 7 Ma. As for its geodynamic background, it may be related still to the extensional-transtensional post-rift phase of basin evolution; similar syn-sedimentary strike-slip faults have been reported from sands of similar age (7.5-5.4 Ma, probably close to $7 \mathrm{Ma}$ ) along the northern margin of the Mecsek Mts. However, the measured faults also fit an approximately N-S oriented compressional stress field, so they might also be linked already to the start of basin inversion.

The whole succession experienced folding by N-S shortening (Fig. 9a) and is also tilted. Fold wavelength is $\sim 200 \mathrm{~m}$, fold axes plunge $20^{\circ}$ to the $\mathrm{W}$. A relatively gently dipping, E-W striking set of faults with normal component was documented in the W wall of the sand pit (Fig. 9c). These faults end within the coarse sand both up- and downwards. Though their temporal relationship with other fault sets is unclear, their orientation suggests that they may belong to the same tectonic event as folding. Considering available data, it is not obvious whether westward tilting is coeval with, or posterior to folding. The compressional event producing the folding and possibly also minor faulting and westward tilting, postdates the accumulation of the preserved sediment column. It indicates $\mathrm{N}-\mathrm{S}$ shortening and is obviously a manifestation of basin inversion, recorded in sands of similar age at several spots elsewhere in the region (Kleb 1973; Csontos et al. 2002; Konrád and Sebe 2010; Sebe et al. 2015).

\section{Depositional model}

\section{Gravelly, arkosic and clayey units}

The gravelly, arkosic unit represents coarse-grained sediments deposited by episodic debris flow and partially grain flow events in a tectonically active zone under subaquatic conditions. Because it has dip angles $5^{\circ}-6^{\circ}$ higher than in the younger units, it probably corresponds to a fan delta environment. As indicated by the grain composition, the emerged granite body (Fig. 1d) formed the catchment area of the delta.

The dominance of debris flows could be a consequence of intense weathering that produced abundant clayey material on the exposed granitic bedrock. The poorly-sorted clayey sediment has low permeability and achieves saturation more rapidly during rain falls which promotes the formation of debris flows (Johnson 1970; Blair 1999b).

The three intervals of the unit correspond to specific subenvironments of the fan-delta (Fig. 10). The lowermost interval, built up by the Sp and Gps facies, lacks any clay content and shows better sorting compared to the middle and upper intervals. These deposits can represent material transported from the wave-reworked delta front to the lower part of the fan delta by less cohesive debris flows, grain flows, or turbidity currents, possibly induced by gravitational collapses (Nemec 1990) (Fig. 10a). This could explain the mixture of littoral and sublittoral mollusks within this interval. Deposition of the coarser Gcs facies implies progradation (Fig. 9b). Based on the presence of littoral mollusks in the Gms facies, however, the fan delta did not reach subaerial exposure, and there is no indication of wave reworking even in the uppermost interval (Fig. 10c).

The fan delta is overlain by the clayey unit which contains a rich sublittoral mollusk assemblage and lacks any coarse clasts or sand intercalations, suggesting depositional water depth below the storm wave base (Fig. 10d). Lack of gradual facies transition between the gravelly arkosic and the clayey units implies abrupt changes in lake level and/or sediment supply. 


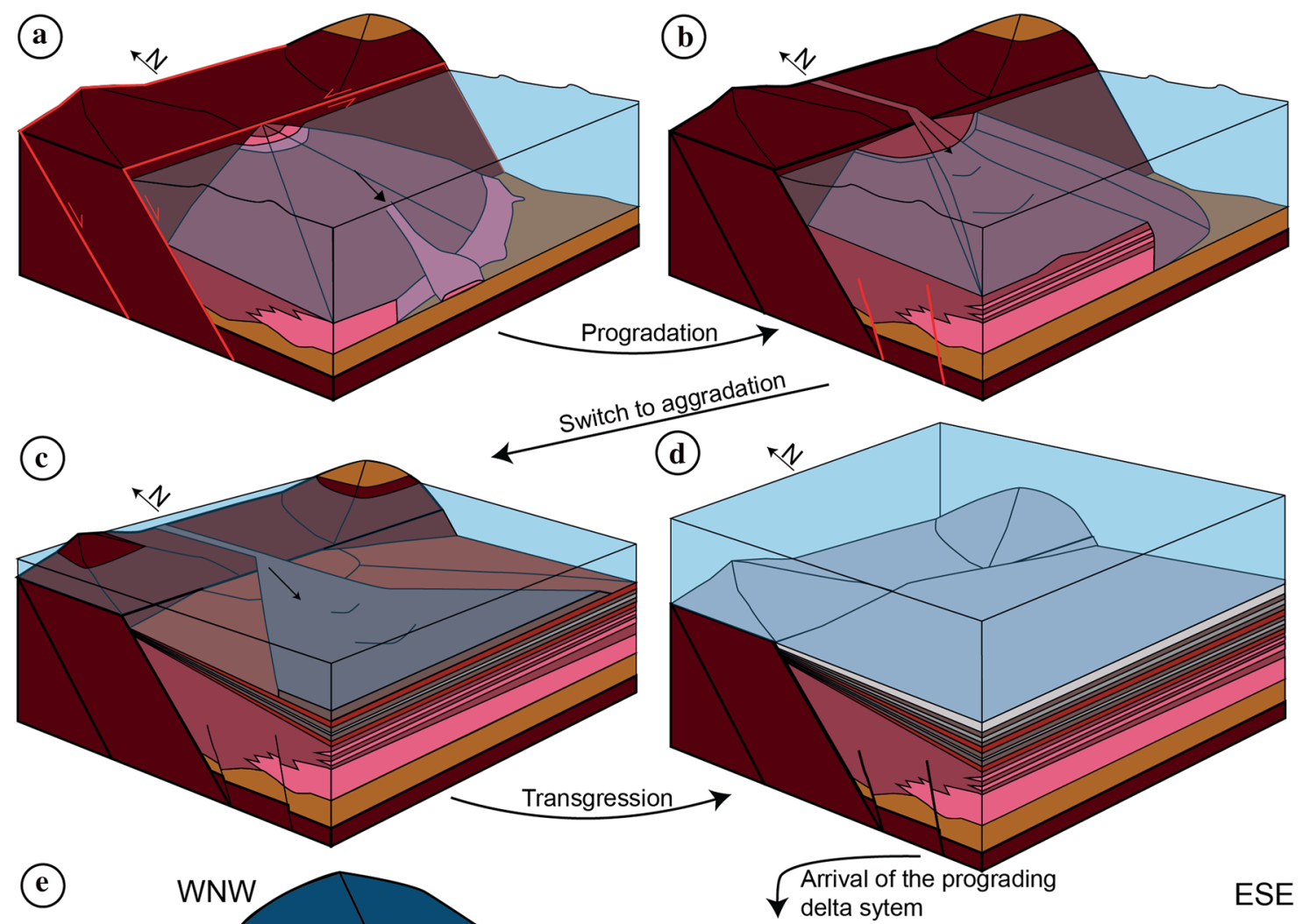

(e)

ESE

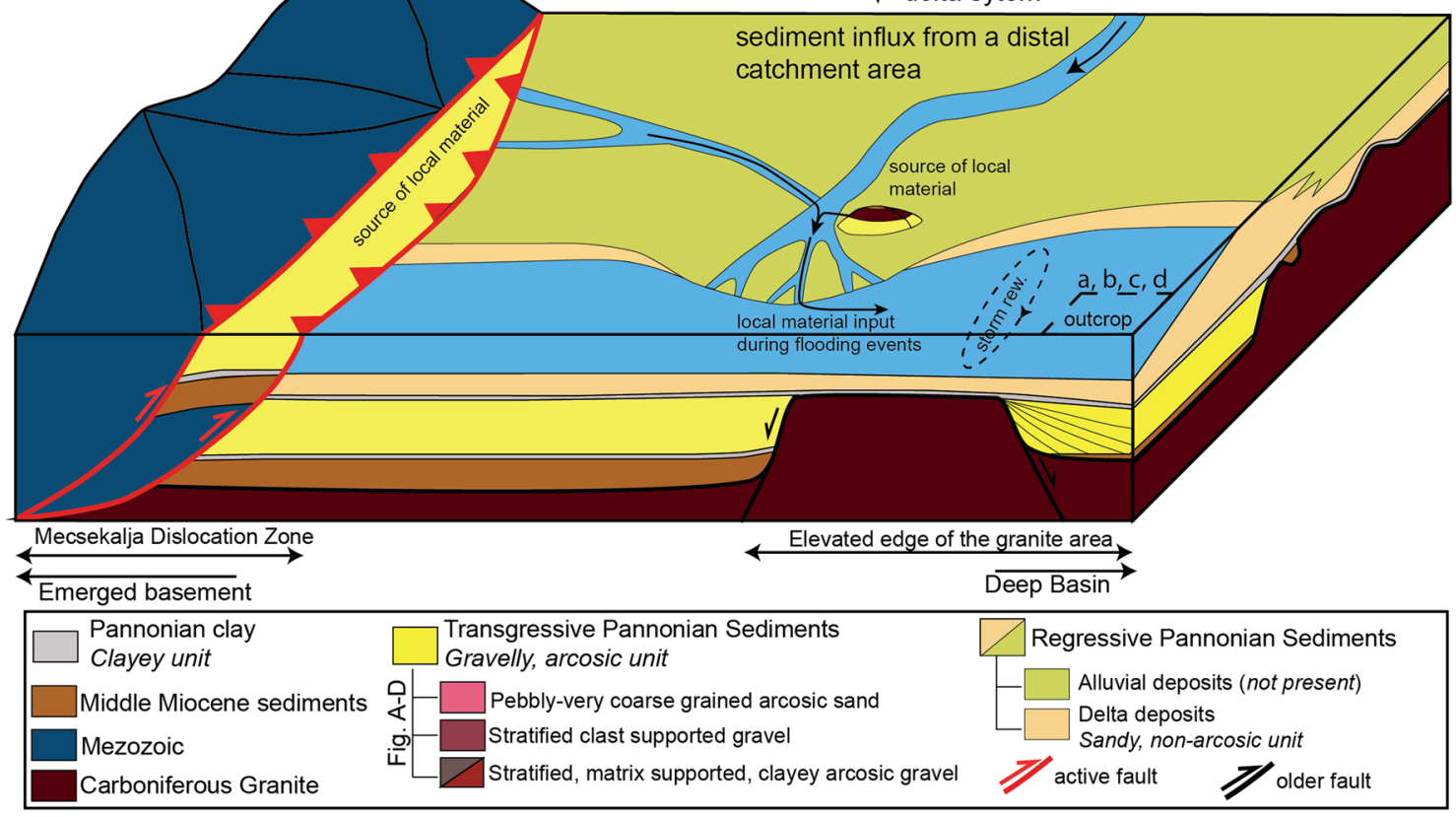

Fig. 10 Summary of the tectonical and sedimentological evolution of the outcrop, showing the individual steps of sedimentation and palaeoenvironmental changes. Figures not to scale. a Depositon of the $\mathrm{Sp}$ facies at the front of the alluvial fan delta during syn-sedimentary tectonic movements. b Deposition of the Gcs facies by mass flow event, representing the progradation of the alluvial fan delta body. $\mathbf{c}$ Depositon of the Gms facies during debris flow events. d Lake level rise and deposition of the clayey mollusk-rich horizon in sublittoral water depth. e Arrival of the remote/distal delta system, deposition of the sandy, non-arkosic unit 


\section{Sandy, non-arkosic unit}

The grain composition of the upper, sandy non-arkosic unit essentially differs from that of the underlying fan delta association. In contrast to the locally-sourced, coarse material, a finer, sandy sediment appears in the study area shed from a different and distal catchment area [based on provenance analysis by Thamó-Bozsó et al. (2014)]. The abrupt appearance of this new, abundant sandy material points to high sediment influx and can be associated with the large paleo-Danube system, carrying sediments from the remote Alpine-Western Carpathian areas. This alluvial to deltaic feeder system comprises the major part of the basin-fill successions of the Late Miocene Lake Pannon (Magyar et al. 2013). The unit corresponds to a shoreface environment developed at the side of a river mouth associated to a larger delta system (Fig. 10e). Similarly to the St. George mouth of the recent Danube delta (Giosan et al. 2005) or to the Cretaceous Notom delta ( $\mathrm{Li}$ et al. 2011, 2015), the bulk of the sand could be deposited by longshore currents.

Beds of Sls, Gfr and Ssf facies within the sandy, nonarkosic unit were deposited by erosive, event flows. Scourfills (Ssf) show a more complete sequence of sedimentary structures, therefore, they give more information about the recurring depositional events. The sequences are built up by sedimentary structures formed under combined flows (i.e., quasi-planar lamination, undulating plane lamination and HCS). Bedform sequences containing HCS and quasiplanar lamination are traditionally linked to storm deposition (Dott and Bourgeois 1982; Brenchley 1989; Myrow 1992; Myrow and Southard 1996; Bhattacharya and Bhattacharya 2005). However, HCS can also be present in the depositional sequences of gravity flows, for instance flood-induced hyperpycnal flows (Mutti et al. 2000, 2003, Lamb et al. 2008; Myrow et al. 2008; Bhattacharya and MacEachern 2009; Tinterri 2011; Basilici et al. 2012; Collins et al. 2017) and even turbidity currents (Myrow et al. 2002, 2008; Lamb et al. 2008).

The usually present granitic grains at the base of the beds of Sls and Ssf facies could be originated from outcropping bedrock on the coast, eroded and transported during storm events. In this case, however, thicker and more frequent laminae of coarse material would be expected. In addition, a longer storage on the shore would increase the roundness of the grains. The local material could also be transported by rivers and deposited on the delta flanking shoreface during flooding events. The same applies to the single gravel bed of the Gfr facies, which contains slightly diagenised, resedimented Pannonian mollusks and older Miocene bioclasts, pointing to erosion and resedimentation of slightly older Miocene sediments (Fig. 10e).

Flooding events and related hyperpycnal plumes can be generated by storm events due to intense rainfall (Collins et al. 2017), which can also cause increased erosion. In addition, flood-induced hyperpycnal flows are capable to enhance the storm generated offshore or alongshore sediment transport. In this way, the beds of Sls facies and the scour fills could be formed during linked storm and flooding events. The role of the latter is dependent on the presence of local material within a scour-fill sequence.

\section{Discussion}

Based on mollusk biostratigraphy, the elevated eastern edge of the granite body near the study site was flooded by Lake Pannon in the Congeria rhomboidea biochron of the Pannonian age, sometime after $8 \mathrm{Ma}$ ago (Magyar and Geary 2012). The observed syn-sedimentary activity of the dextral strike-slip faults suggests that submergence might have been related to an increased rate of local subsidence due to tectonic movements. However, the displacement along the faults is small, so there must have been further control on relative lake level change. Considering the wider picture, the flooding of the study area happened coevally with that of the whole Mecsek region (Sebe et al. 2015), referring to a regional process. At the same time period there exist signs referring to basinwide lake level rise as well, attributed to increased precipitation (Magyar 2010). Thus, base-level rise in the study area most likely resulted both from local tectonic events and from regional factors. Whether the latter affected only the Mecsek region or the entire Pannonian Basin is not obvious; for a detailed discussion see Sztanó et al. (2015).

Sedimentation in the study area started with the deposition of a fan delta body (Fig. 10).

The delta was dominantly fed by debris flow events possibly due to the intense clay producing weathering of the granite body. The change between the Sps and Gcs facies implies progradation. As the delta body remained subaqueous during its formation, it is possible that the sediment influx could not exceed the continuing lake level rise during the formation of the uppermost interval. The lack of facies changes within the uppermost part suggests phase aggradation (Fig. 10c). The sudden appearance and deposition of the overlying shallow sublittoral clayey unit (Fig. 10d) was most probably resulted by the culmination of the base-level rise which led to a complete and abrupt cut-off from the granitic source. This sudden cessation of sediment supply could be the effect of the inundation and submergence of the entire catchment area or the absence of available transporting agents that were capable to carry material from the still subaerially exposed bedrock.

As the fan delta system is composed predominantly of the locally sourced material, the shelf edge must have been located further northward from the Mecsek during its 
deposition (Fig. 1c). The sharp-based, storm-flood influenced, lower shoreface succession (sandy, non-arkosic unit) (Fig. 10e) mirrors the progradation of the shelf slope system to the area. Based on nearby seismic data from deep basins (Magyar et al. 2013), this could happen around $6.8 \mathrm{Ma}$ ago (Fig. 1c). This means that only a short time could have elapsed between the flooding of the area and the arrival of the prograding delta system, and it places the formation of the alluvial fan delta somewhere between 8 and 6.8 Ma.

The sharp boundary between the shallow sublittoral clay and the littoral shoreface deposits could be interpreted as a sign of a minor local relative lake level drop, produced by a compressional event (Csontos et al. 2002; Konrád and Sebe 2010) at the time. This caused an ensuing erosion and transportation of material originated from the bedrock and from coarse-grained transgressive sediments representing the same biozone as the sandy, non-arkosic unit. This was manifested in the thin coarse laminae of the Sls, Ssf facies and the sole bed of the Gfr facies. The local material was most likely transported by fluvial flows and deposited during coupled storm-flood events on the delta flanking shoreface environment. The lack of any horizontal facies change within the considerable thickness (ca. $30 \mathrm{~m}$ ) of the sandy, non-arkosic unit indicates constant lake level rise during deposition and a sediment influx that could keep up with it. As other delta sediments in the basin are usually characterized by 5-8 $\mathrm{m}$ thick shallowing upward parasequences and 30-50 m thick fourth-order sequences (Sztanó et al. 2013; Bartha et al. 2015), this feature may point towards an increased subsidence rate in the area of the outcrop compared to other areas. The upper occurrence of the clayey unit (Fig. 3) atop the sandy, non-arkosic unit implies that the lake level rise exceeded the sediment supply at the time of its deposition.

It is important that the locally sourced fan delta body and the delta sediments fed by the prograding, distally sourced system represent nearly the same, relatively shallow water depth. Profundal marls or turbiditic sandstone bodies are missing in the succession; the clayey unit presents the deepest environment. This indicates that several 100 -m deep water could not develop in the area. Rather, the whole marginal area of the present Mecsek mountains acted as a shallow sublacustrine high where delta bodies could form, similarly to other basement highs in the Pannonian Basin (Sztanó et al. 2013, 2015; Bartha et al. 2015; Magyar et al. 2017). Unfortunately, the subsequent events cannot be traced, because post-Miocene erosion truncated the Pannonian sediments and Quaternary loess covers the whole section. Folding of the sequence took place after the deposition of the sandy unit, as a consequence of the above discussed compressional regime.

\section{Conclusions}

The studied Upper Miocene sedimentary sequence documents the superimposition of a locally-sourced, coarsegrained delta and a younger, sandy delta body fed by a different, distal sediment source, in the marginal area of an intrabasinal basement high called Mecsek "island" within Lake Pannon. Biostratigraphic data constrain the age of sedimentation between $\sim 8$ and $6.5 \mathrm{Ma}$. Sedimentation was controlled by relatively often changing interplay of tectonic factors and lake-level changes. The studied sequence of the outcrop allows us to reconstruct the following steps:

1. The area was flooded by Lake Pannon sometimes after $8 \mathrm{Ma}$ ago due to local, syn-sedimentary structural movements and a regional relative lake-level rise. This led to the deposition of a fan delta fed from the exposed granite body of the basement high. The facies structure of the delta indicates progradation followed by aggradation.

2. Deposition of a clayey unit with shallow sublittoral mollusks points to cut-off from the granitic source thus submergence of the granite body.

3. The onset of deposition of the overlying sandy unit indicates the arrival of a distally-sourced delta system of the lake to the region. It brought well sorted, mature sediment from the Alpine-Carpathian catchment area. The scour-fill structures in the unit imply intensive storm sedimentation with the contribution of flood-induced hyperpycnal flows. Thin, coarse laminae at the base of the scour fills indicate recurring resedimentation of local material (granite, and older Miocene sediments), possibly due to minor lake level drops.

4. The sequence of facies shows that profundal marls and turbiditic successions are missing at the transition between the two delta systems. This means that only shallow water covered the elevated basement where regressive deltaic bodies could form.

5. The sequence was later folded and tilted, evidently associated to the increasingly stronger compressional stress regime of the basin inversion phase. This compression eventually resulted in the uplift and erosional truncation of the lacustrine sediments, probably in post-Miocene times.

Acknowledgements Open access funding provided by Eötvös Loránd University (ELTE). Research was supported by the European Union and the State of Hungary, co-financed by the European Social Fund in the framework of TÁMOP 4.2.4. A/2-11-1-2012-0001 'National Excellence Program', by the Hungarian National Research, Development and Innovation Office (NKFI) projects PD104937 and K116618, and by the János Bolyai Research Scholarship of the Hungarian Academy of Sciences. This is MTA-MTM-ELTE Paleo contribution no. 295. 
Open Access This article is distributed under the terms of the Creative Commons Attribution 4.0 International License (http://creativeco mmons.org/licenses/by/4.0/), which permits unrestricted use, distribution, and reproduction in any medium, provided you give appropriate credit to the original author(s) and the source, provide a link to the Creative Commons license, and indicate if changes were made.

\section{References}

Allen JRL (1973) A classification of climbing-ripple cross-lamination. J Geol Soc Lond 129:537-541

Arnott RWC (1993) Quasi-planar-laminated sandstone beds of the lower cretaceous bootlegger member, North-Central Montana: evidence of combined-flow sedimentation. J Sediment Petrol 63:488-494

Arnott RWC, Southard JB (1990) Exploratory flow-duct expreiments on combined-flow bed configurations, and some implications for interpreting storm-event stratification. J Sediment Petrol 60:211-219

Ashley GM, Southard JB, Boothroyd JC (1982) Deposition of climbing-ripple beds: a flume simulation. Sedimentology 29:67-79

Balázs A, Matenco L, Magyar I, Horváth F, Cloetingh S (2016) The link between tectonics and sedimentation in back-arc basins: new genetic constraints from the analysis of the Pannonian Basin. Tectonics 35:1526-1559

Balla Z, Gyalog L (2009) Geology of the North-eastern part of the Mórágy block. Geological Institute of Hungary. Mining and Geological Survey of Hungary, Budapest (in Hungarian)

Bartha I, Magyar I, Fodor L, Csillag G, Lantos Z, Tőkés L, Sztanó O (2015) Lake Pannon Deltaic deposits in Gerecse hills, Hungary. In: Abstract book of 31st IAS meeting of sedimentology: international association of sedimentologists, p 54

Basilici G, de Luca PHV, Poiré DG (2012) Hummocky cross-stratification-like structures and combined-flow ripples in the Punta Negra Formation (Lower-Middle Devonian, Argentine Precordillera): a turbiditic deep-water or storm-dominated prodelta inner-shelf system? Sediment Geol 267-268:73-92

Bhattacharya HN, Bhattacharya B (2005) Storm event beds in a Paleoproterozoic rift basin, Aravalli supergroup, Rajasthan, India. Gondwana Res 8:231-239

Bhattacharya JP, MacEachern JA (2009) Hyperpycnal rivers and prodeltaic shelves in the Cretaceous seaway of North America. J Sediment Res 79:184-209

Bhattacharya HN, Bhattacharya B, Chakraborty I, Chakraborty A (2004) Sole marks in storm event beds in the Permo-Carboniferous Talchir Formation, Raniganj Basin, India. Sediment Geol 166:209-222

Blair TC (1999a) Sedimentology of the debris- flow-dominated Warm Spring Canyon alluvial fan, Death Valley, California. Sedimentology 46:941-965

Blair TC (1999b) Cause of dominance by sheet-flood vs. debris- flow processes on two adjoining alluvial fans, Death Valley, California. Sedimentology 46:1015-1028

Brenchley PJ (1989) Storm sedimentation. Geol Today 5:133-137

Collins DS, Johnson HD, Allison PA, Guilpain P (2017) Coupled "storm-flood" depositional model: application to the MioceneModern Baram Delta Province, north-west Borneo. Sedimentology 64:1203-1235

Csontos L, Benkovics L, Bergerat F, Mansy JL, Wórum G (2002) Tertiary deformation history from seismic section study and fault analysis in a former European Tethyan margin (the Mecsek-Villany area SW Hungary). Tectonophysics 357:81-102

Cziczer I, Magyar I, Pipík R, Böhme M, Ćorić S, Bakrač K, SütőSzentai M, Lantos M, Babinszki E, Müller P (2009) Life in the sublittoral zone of long-lived Lake Pannon: paleontological analysis of the Upper Miocene Szák Formation, Hungary. Int J Earth Sci 98:1741-1766

Dott RH, Bourgeois J (1982) Hummocky stratification: significance of its variable bedding sequences. Geol Soc Am Bull 8:663-680

Dumas S, Arnott RWC (2006) Origin of hummocky and swaley crossstratification - the controlling influence of unidirectional current strength and aggradation rate. Geology 34:1073-1076

Dumas S, Arnott RWC, Southard JB (2005) Experiments on oscillatory-flow and combined-flow bed forms: implications for interpreting parts of the shallow-marine sedimentary record. J Sediment Res 75:501-513

Eoff JD (2014) Sedimentary facies of the upper Cambrian (Furongian; Jiangshanian and Sunwaptan) Tunnel City Group, Upper Mississippi Valley: new insight on the old stormy debate. Sediment Geol 302:102-121

Fernández J, Bluck BJ, Viseras C (1993) The effects of fluctuating base level on the structure of alluvial fan and associated fan delta deposits: an example from the Tertiary of the Betic Cordillera, Spain. Sedimentology 40:879-893

Fodor L, Csontos L, Bada G, Győrfi I, Benkovics L (1999) Tertiary tectonic evolution of the Pannonian basin system and neighbouring orogens: a new synthesis of palaeostress data. Geol Soc Lond Spec Publ 156:295-334

Fossen H, Schultz RA, Shipton ZK, Mair K (2007) Deformation bands in sandstone: a review. J Geol Soc Lond 164:755-769

Gawthorpe RL, Fraser AJ, Collier REL (1994) Sequence stratigraphy in active extensional basins: implications for the interpretation of ancient basin-fills. Mar Pet Geol 11:642-658

Ghinassi M (2007) The effects of differential subsidence and coastal topography on high-order transgressive-regressive cycles: Pliocene nearshore deposits of the Val d'Orcia Basin, Northern Apennines, Italy. Sediment Geol 202:677-701

Giosan L, Donnelly JP, Hole W, Buonaiuto FS (2005) River delta morphodynamics: exmaples from the Danube delta. Soc for Sediment Geol Spec Publ 83:393-412

Hamblin AP, Walker RG (1979) Storm-dominated shallow marine deposits: the Fernie-Kootenay (Jurassic) transition, southern Rocky Mountains. Can J Earth Sci 16:1673-1690

Hámor G (1970) Miocene of the eastern Mecsek Mts. Mining and Geological Survey of Hungary, Budapest (in Hungarian and German)

Horváth F, Cloetingh S (1996) Stress-induced late-stage subsidence anomalies in the Pannonian basin. Tectonophysics 266:287-300

Horváth F, Royden L (1981) Mechanism for formation of the intraCarpathian basins: a review. Earth Evol Sci 1:307-316

Horváth F, Tari G (1999) IBS Pannonian Basin project: a review of the main results and their bearings on hydrocarbon exploration. Geol Soc Lond Spec Publ 156:195-213

Jonhson AM (1970) Formation of debris flow deposition. In: Johnson AM (ed) Physical processes in geology. Freeman Cooper, Sand Francisco, pp 433-448

Jopling AV, Walker RG (1968) Morphology and origin of ripple-drift cross-lamination, with examples from the Pleistocene of Massachusetts. J Sediment Petrol 38:971-984

Kazár E (2005) A new kentriodontid (Cetacea: Delphinoidea) from the Middle Miocene of Hungary seum managed to buy a fossil dolphin skeleton. Mitteilungen aus dem Museum für Naturkde in Berlin 8:53-73

Kleb B (1973) Geology of the Pannon in the Mecsek Mts. Mining and Geological Survey of Hungary, Budapest (in Hungarian)

Kocsis L, Vennemann TW, Hegner E, Fontignie D, Tütken T (2009) Constraints on Miocene oceanography and climate in the Western and Central Paratethys: O-, Sr-, and Nd-isotope compositions of marine fish and mammal remains. Palaeogeogr Palaeoclimatol Palaeoecol 271:117-129 
Konrád G, Sebe K (2010) New records of young tectonic phenomena in the Western Mecsek Mts. and their surroundings. Földtani Közlöny 140:135-162 (in Hungarian with English abstract)

Lamb MP, Myrow PM, Lukens C, Houck K, Strauss J (2008) Deposits from wave-influenced turbidity currents: Pennsylvanian minturn formation, Colorado, USA. J Sediment Res 78:480-498

Leclair SF, Arnott RWC (2005) Parallel lamination formed by highdensity turbidity currents. J Sediment Res 75:1-5

Leeder MR, Harris T, Kirkby MJ (1998) Sediment supply and climate change: implications for basin stratigraphy. Basin Res 10:7-18

Li W, Bhattacharya JP, Zhu Y, Garza D, Blankenship E (2011) Evaluating delta asymmetry using three-dimensional facies architecture and ichnological analysis, Ferron "Notom Delta", Capital Reef, Utah, USA. Sedimentology 58:478-507

Li Z, Bhattacharya J, Schieber J (2015) Evaluating along-strike variation using thin-bedded facies analysis, Upper Cretaceous Ferron Notom Delta, Utah. Sedimentology 62:2060-2089

Lin C, Liu S, Zhuang Q, Steel RJ (2018) Sedimentation of Jurassic fan-delta wedges in the Xiahuayuan basin reflecting thrust-fault movements of the western Yanshan fold-and-thrust belt, China. Sediment Geol 368:24-43

López-Blanco M, Marzo M, Burbank DW, Vergés J, Roca E, Anadón P, Piña J (2000) Tectonic and climatic controls on the development of foreland fan deltas: Montserrat and Sant Llorenç del Munt systems (Middle Eocene, Ebro Basin, NE Spain). Sediment Geol 138:17-39

Lowe DR (1982) Sediment gravity flows: II. Depositional models with special reference to the deposits of high-density turbidity currents. J Sediment Petrol 52:279-297

Magyar I (2010) Palaeogeography and palaeoenvironments in the Late Miocene Pannonian Basin. GeoLitera, Szeged (in Hungarian)

Magyar I, Geary DH (2012) Biostratigraphy in a Late Neogene Caspian-type lacustrine basin. In: Baganz OV, Bartov Y, Bohács K (eds) Lacustrine sandstone reservoirs and hydrocarbon systems. AAPG Memoir, vol 95, pp 255-264

Magyar I, Geary DH, Müller P (1999) Paleogeographic evolution of the Late Miocene Lake Pannon in Central Europe. Palaeogeogr Palaeoclimatol Palaeoecol 147:151-167

Magyar I, Juhász G, Szurominé Korecz A, Sütôné Szentai M (2004) The Tótkomlós Calcareous Marl Member of the Lake Pannon sedimentary sequence in the Battonya-Pusztaföldvár region. SE Hungary Földtani Közlöny 134:521-540 (in Hungarian with English abstract)

Magyar I, Radivojević D, Sztanó O, Synak R, Ujszászi K, Pócsik M (2013) Progradation of the paleo-Danube shelf margin across the Pannonian Basin during the Late Miocene and Early Pliocene. Glob Planet Change 103:168-173

Magyar I, Sztanó O, Cs Gábor, Kercsmár Z, Katona L, Lantos Z, Bartha IR, Fodor L (2017) Pannonian molluscs and their localities in the Gerecse Hills, Transdanubian range: stratigraphy, palaeoenvironment, geological evolution. Földtani Közlöny 147:149-176 (in Hungarian with English abstract)

Martini I, Ambrosetti E, Sandrelli F (2017) The role of sediment supply in large-scale stratigraphic architecture of ancient Gilbert-type deltas (Pliocene Siena-Radicofani Basin, Italy). Sediment Geol 350:23-41

Martins-Neto MA (1996) Lacustrine fan-deltaic sedimentation in a Proterozoic rift basin: the Sopa-Brumadinho Tectonosequence, southeastern Brazil. Sediment Geol 106:65-96

McCallum JE, Robertson AHF (1995) Sedimentology of two fandelta systems in the Pliocene-Pleistocene of the Mesaoria Basin, Cyprus. Sediment Geol 98:215-244

Muravchik M, Bilmes A, D'Elia L, Franzese JR (2014) Alluvial fan deposition along a rift depocentre border from the Neuquén Basin, Argentina. Sediment Geol 301:70-89
Mutti E, Tinterri R, di Biase D, Fava L, Mavilla N, Angella S, Calabrese L (2000) Delta-front facies associations of ancient flood dominated fluvio-deltaic systems. Rev Soc Geol Esp 13:165-190

Mutti E, Tinterri R, Benevelli G, di Biase D, Cavanna G (2003) Deltaic, mixed and turbidite sedimentation of ancient foreland basins. Mar Pet Geol 20:733-755

Myrow PM (1992) Pot and gutter casts from the Chapel Island Formation, southeast Newfoundland. J Sediment Res 62:992-1007

Myrow PM, Southard JB (1996) Tempestite deposition. J Sediment Res 66:875-887

Myrow PM, Fischer W, Goodge JW (2002) Wave-modified turbidites: combined-flowshoreline and shelf deposits, Cambrian, Antarctica. J Sediment Res 72:641-656

Myrow PM, Lukens C, Lamb MP, Houck K, Strauss J (2008) Dynamics of a transgressive prodeltaic system: implications for geography and climate within a Pennsylvanian Intracratonic Basin, Colorado, USA. J Sediment Res 78:512-528

Nemec W (1990) Aspects of sediment movement on steep delta slopes. In: Colella A, Prior DB (eds) Coarse-grained deltas. Blackwell Publishing Ltd., Oxford, pp 29-73

Nemec W, Steel RJ (1988) What is fan delta and how do we recognize it? In: Nemec W, Steel RJ (eds) Fan deltas: sedimentology and tectonic setting. Blackie, Glasgow, pp 3-13

Postma G (1995) Sea-level-related architectural trends in coarsegrained delta complexes. Sediment Geol 98:3-12

Sebe K, Csillag G, Dulai A, Gasparik M, Magyar I, Selmeczi I, Szabó M, Sztanó O, Szuromi-Korecz A (2015) Neogene stratigarphy in the Mecsek region. In: 6th workshop on the Neogene of Central and South-Eastern Europe (Orfü), Budapest

Steel RJ (1976) Devonian basins of western Norway—sedimentary response to tectonism and to varying tectonic context. Tectonophysics 36:207-224

Swift DJP, Figueiredo AG, Freeland GL, Oertel GF (1983) Hummocky cross-stratification and megaripples; a geological double standard? J Sediment Res 53:1295-1317

Sztanó O, Magyar I, Szónoky M, Lantos M, Müller P, Lenkey L, Katona L, Csillag G (2013) Tihany Formation in the surroundings of Lake Balaton: type locality, depositional setting and stratigraphy. Földtani Közlöny 143:73-98 (in Hungarian with English abstract)

Sztanó O, Sebe K, Csillag G, Magyar I (2015) Turbidites as indicators of paleotopography, Late Miocene Lake Pannon, Western Mecsek, Hungary. Geol Carpathica 66:331-344

Sztanó O, Kováč M, Magyar I, Šujan M, Fodor L, Uhrin A, Rybár S, Csillag G, Tőkés L (2016) Late Miocene sedimentary record of the Danube/Kisalföld Basin: interregional correlation of depositional systems, stratigraphy and structural evolution. Geol Carpathica 67:525-542

Talling PJ, Masson DG, Sumner EJ, Malgesini G (2012) Subaqueous sediment density flows: depositional processes and deposit types. Sedimentology 59:1937-2003

Tari G, Horváth F (1992) Styles of extension in the Pannonian Basin. Tectonophysics 208:203-219

Thamó-Bozsó E, Sebe K, Kónya P (2014) An attempt to distinguish local and distal Upper Miocene deltaic sediments around the Mecsek Mountains (SW Hungary) based on mineralogical data. In: Bábek O, Matys GT, Uličný D (eds) Central European Meeting of Sedimentary Geology. Olomouc, Czech Republic, Abstracts, pp 102-103

Tinterri R (2011) Combined flow sedimentary structures and the genetic link between sigmoidal- and hummocky-cross stratification combined flow sedimentary structures and the genetic link between sigmoidal- and hummocky-cross stratification. GeoActa $10: 43-85$ 
Wagreich M, Strauss PE (2005) Source area and tectonic control on alluvial-fan development in the Miocene Fohnsdorf intramontane basin, Austria. Geol Soc Lond Spec Publ 251:207-216

Walker RG, Duke WL, Leckie DA (1982) Discussion on: hummocky stratification: significance of its variable bedding sequences: discussion and reply. Geol Soc Am Bull 94:1245-1251
Yokokawa M, Masuda F, Endo N (1995) Sand particle movement on migrating combined-flow ripples. J Sediment Res 65:40-44

Zhang C, Muirhead JD, Wang H, Chen S, Liao Y, Lu Z, Wei J (2018) Lacustrine fan delta deposition alongside intrabasinal structural highs in rift basins: an example from the Early Cretaceous Jiuquan Basin, Northwestern China. Int J Earth Sci 107:1835-1858 